182

Received: February 14, 2014

Accepted: May 16, 2014
Macedonian Journal of Animal Science, Vol. 4, No. 1, pp. 23-26 (2014)

In print: ISSN $1857-6907$

On line: ISSN $1857-7709$

UDC: $633.1-114.7$

Original scientific paper

\title{
QUALITY PROPERTIES OF CEREAL CROP IN RELATION WITH ORGANIC VERSUS CONVENTIONAL FARMING
}

\author{
Mirjana Menkovska ${ }^{1}$, Vesna Levkov ${ }^{1}$, Natasha Gjorgovska ${ }^{1}$, Nedeljka Nikolova ${ }^{1}$, \\ Nikola Pacinovski ${ }^{1}$, Vinko Stanoev ${ }^{2}$, Mihajlo Nikolovski ${ }^{2}$ \\ 1 "Ss. Cyril and Methodius" University in Skopje, Institute of Animal Science, \\ Blvd. Ilinden 92a, 1000 Skopje, Republic of Macedonia \\ 2 "Ss. Cyril and Methodius" University in Skopje, Institute of Agriculture, \\ Blvd. Aleksandar Makedonski bb, 1000 Skopje, Republic of Macedonia \\ Menkovska06@yahoo.com
}

\begin{abstract}
The interest for food organic production is insreasing in the EU, what was reflected to our country. Cereals, especially wheat, are the major food in the human nutrition, and an important feed ingredient. The aim of this work was some quality properties of different cereals organically grown (wheat, barley, rye, oat and millet) to be determined in comparison with those of conventionally grown cereals. Standard methods of analysis of cereal quality properties were applied. The results obtained from the investigations have shown an increasing of the values of quality properties with organically grown cereals in regard to those of conventioanally grown cereals. The increase of ash content was $15 \%$ with wheat, $7 \%$ with barley and even $71 \%$ with millet. The crude protein content was decreased with barley of $15 \%$, while with oat and rye an increase of $37 \%$ and $3 \%$, respectively. Crude fat content has increased $15 \%$ with wheat, $3 \%$ with oat, $29 \%$ with rye and $7 \%$ with millet. These results are significant because they have pointed out that, besides for the safety, organic farming have a potentional for improving the cereal quality properties.
\end{abstract}

Key words: cereals; quality properties; farming methods

\section{КВАЛИТЕТНИ СВОЈСТВА НА ЖИТАТА ВО СПОРЕДБА НА ОРГАНСКОТО И КОНВЕНЦИОНАЛНОТО ПРОИЗВОДСТВО}

\begin{abstract}
Интересот за органско производство на храна во ЕУ се зголемува, што има одраз и во нашата земја. Житата, особено пченицата, се основна храна во хуманата исхрана и значајна состојка на добиточната храна. Целта на овој труд беше да се определат некои квалитетни својства на разни органски одгледани жита (пченица, јачмен, 'рж, овес и просо) во споредба со житата одгледани конвенционално. Беа применети стандардни методи на анализа на квалитетните својства на житата. Резултатите добиени од истражувањата покажаа зголемување на вредностите на квалитетните својства на органски одгледаните жита во споредба со конвенционално одгледаните. Зголемувањето на содржината на пепелта изнесуваше $15 \%$ кај пченицата, $7 \%$ кај јачменот и дури $71 \%$ кај просото. Кај содржината на сурови протеини имаше намалување кај јачменот за $15 \%$, додека кај овесот и 'ржта е забележано зголемување од $37 \%$ и $3 \%$, соодветно. Содржината на сурови масти беше зголемена за $15 \%$ кај пченицата, 3\% кај овесот, $29 \%$ кај 'ржта и $7 \%$ кај просото. Овие резултати се значајни бидејќи укажуваат на тоа дека покрај безбедноста, органското производство има потенцијал за подобрување на квалитетните својства на житата.
\end{abstract}

Клучни зборови: жита; квалитетни својства; методи на одгледување

\section{INTRODUCTION}

Taking into account the great importance of cereals for their usage in animal and human nutrition for the growth and the health [1,2], we have undertook few investigations in the past on cereals which were grown by conventional farming. So, the chemical composition of some cereals and their processed products were determined [3]. The influence of climate factors during the kernel maturation on some qualitative characteristics of wheat was investigated [4], revealing that wheat technological quality for milling and baking industry can be predicted with higher probability using analysis 
of climate factors during the kernel maturation. Nutritional value of some cereals was also investigated [5-7]. Comparative analysis of nutrients contained in wheat and corn grown in different agroecological regions [8], and between wheat and barley [9] was done. Bread wheat varieties varying widely in their bread making quality, grown in three different subregions of a region under the same conditions, were investigated for their starch and crude fiber content [10]. On the basis of the obtained results from the investigations it was concluded that on the cereal nutritive value influence have both the growing region and the cereal genotype, and that it has also differed within a region.

Antinutritive components in cereals including animal feed were also investigated [11] determinating the components which are responsible for deleterious effects on bioavailability of nutrients and macronutrients, some of them having healthful effects [12].

Organic farming represents a way of producing food that respects natural life cycles, minimising the human impact on the environment and operating as naturally as possible, in accordance with objectives and principles including rotating of crops. On-site resources are used efficiently chemical pesticides, synthetic fertilisers, antibiotics and other substances are severely restricted, genetically modified organisms (GMOs) are banned, on-site resources are put to good use, such as manure for fertiliser or feed produced on the farm, and disease-resistant plant and animal species adapted to the local environment are used [13].

Organic farming is part of an extensive supply chain, which also includes food processing, distribution and retailing. Each link in this chain aims to deliver the benefits of organic food production in terms of consumer confidenece, environmental protection, food quality, and animal welfare. The EU has developed comprehensive rules on organic production, processing, distribution, labelling and controls $[14,15]$. The low for organic agricultural production, food products and food in Republic of Macedonia was introduced in 2009, and changes and supplements in 2011 [16]. Since the implementing period for organic farming in our country is short, there is still besides organic production, production in conversion towards the organic, and limited choice of organic crops.

The aim of this work was a comparative analysis of some quality properties of the cereal crop collected from different geographical locations in Republic of Macedonia to be conducted, in order to find out the influence of the farming method (organic versus conventional) on the cereal quality.

\section{MATERIALS AND METHODS}

Material: The choice of cereal samples depended on the cereal organic and conventional production available. So 7 samples of wheat, 7 samples of barley, 5 samples of oats, 3 samples of rye and 3 samples of millet were used for analysis of content of moisture, ash, crude protein and crude fat. Cereals were grown in tree different agro-ecological regions in Republic of Macedonia: Štip-Ovče Pole, Veles and Negotino. Organic and conventional method of farming was applied for cereals during 2013. For wheat, barley and oat, the samples were collected from conventional, organic and in conversion production, while for rye and millet the samples were collected from conventional and organic production.

Methods: The grain was milled and carried out in plastic containers at room temperature before chemical analysis. The flour of each crop was evaluated for moisture content by using an oven at a temperature of $105 \pm 5^{\circ} \mathrm{C}$. Total protein content was determinated according to the Kjeldahl's method $(\mathrm{N} \times 5.7)$. The total fat was analyzed with extraction with diethyl ether according Soxhlet protocol. The grain ash was determinate by burning them in furnace during 8 hours on temperature of $600^{\circ} \mathrm{C}$.

\section{RESULTS AND DISCUSSION}

The results obtained from the investigations are presented in Table 1.

The following findings were obtained for the cereal samples analyses:

1. Wheat: Among the all quality properties analyzed, the maximal values were obtained for ash content and dry matter content in organic farming ( 1.57 and $90.10 \%$, respectively), while minimal values were obtained in conventional farming $(1.36 \%$ and $87.92 \%$, respectively). The increase in ash contents comparing conventional farming and organic farming was $15 \%$. In regard to the protein and fat contents maximal values were obtained in conversion, and protein contents of organic and conventional production were similar (12.24 and $12.22 \%$, respectively). The increase of crude protein and crude fat contents comparing in conversion and organic farming was $16 \%$ and $15 \%$, respectively. 
Table 1

Some quality properties of different cereals grown on conventional and organic farming ${ }^{a}(\%)$

\begin{tabular}{llrcccc}
\hline \hline Cereal & Farming & Moisture & \multicolumn{1}{c}{ Ash } & Protein & Fat & Dry matter \\
\hline \multirow{4}{*}{ Wheat } & Conventional & $12.08 \pm 0.35$ & $1.36 \pm 0.04$ & $12.24 \pm 0.22$ & $1.53 \pm 0.28$ & $87.92 \pm 0.35$ \\
& Organic & $9.90 \pm 2.01$ & $1.57 \pm 0.07$ & $12.22 \pm 3.92$ & $1.64 \pm 0.44$ & $90.10 \pm 2.02$ \\
& In conversion & $11.38 \pm 0.32$ & $1.51 \pm 0.03$ & $14.21 \pm 0.42$ & $1.88 \pm 0.22$ & $88.62 \pm 0.33$ \\
\hline \multirow{*}{*}{ Barley } & Conventional & $11.02 \pm 0.47$ & $2.38 \pm 0.13$ & $12.40 \pm 0.62$ & $1.80 \pm 0.29$ & $88.98 \pm 0.47$ \\
& Organic & $7.99 \pm 3.51$ & $2.56 \pm 0.18$ & $10.52 \pm 1.27$ & $1.28 \pm 0.23$ & $92.01 \pm 3.51$ \\
& In conversion & $9.87 \pm 0.36$ & $2.30 \pm 0.63$ & $13.64 \pm 0.92$ & $2.16 \pm 0.36$ & $90.14 \pm 0.36$ \\
\hline \multirow{6}{*}{ Oat } & Conventional & $10.54 \pm 1.22$ & $3.40 \pm 0.31$ & $12.98 \pm 2.12$ & $3.93 \pm 0.49$ & $89.46 \pm 1.22$ \\
& Organic & $10.05 \pm 3.01$ & $3.17 \pm 0.13$ & $13.60 \pm 1.53$ & $4.04 \pm 0.23$ & $89.95 \pm 0.65$ \\
& In conversion & $9.72 \pm 0.55$ & $2.90 \pm 0.05$ & $12.91 \pm 0.41$ & $3.72 \pm 0.25$ & $90.28 \pm 0.23$ \\
\multirow{2}{*}{ Rye } & Conventional & $14.29 \pm 1.05$ & $1.61 \pm 0.07$ & $7.62 \pm 0.92$ & $1.31 \pm 0.29$ & $85.71 \pm 0.23$ \\
& Organic & $11.56 \pm 0.21$ & $1.66 \pm 0.06$ & $10.41 \pm 1.55$ & $1.70 \pm 0.19$ & $88.45 \pm 0.21$ \\
\multirow{2}{*}{ Millet } & Conventional & $11.95 \pm 0.87$ & $153 \pm 0.77$ & $11.28 \pm 1.54$ & $3.28 \pm 0.24$ & $88.05 \pm 0.87$ \\
& Organic & $11.21 \pm 2.04$ & $2.62 \pm 0.18$ & $11.62 \pm 2.01$ & $3.52 \pm 0.44$ & $88.79 \pm 1.22$ \\
\hline \hline
\end{tabular}

${ }^{\mathbf{a}}$ The values are means \pm S.D.; ${ }^{\mathbf{b}}$ Crude protein; ${ }^{\mathbf{c}}$ Crude fat

2. Barley: The maximal ash and dry matter value was determined in organic farming of $2.56 \%$ and $92.01 \%$, respectively, and comparing with conventional farming the increase was $7 \%$ and $3 \%$, respectively. The maximal value for protein content was determined for conversion, and the increase comparing with conventional farming was $10 \%$, while decrease in organic farming comparing with conventional was $15 \%$. The minimal fat content was determined for organic farming (1.28\%) and the decrease in regard to conventional farming was $40 \%$.

3. Oat: Ash and dry matter content were similar for conventional and organic farming (3.40\% versus $3.17 \%$, and $89.46 \%$ versus $89.95 \%$, respectively). The minimal fat value was obtained in conversion $(2.90 \%)$. The dry matter value was the maximal in conversion (90.28\%), and comparing with conventional farming the increase was $1 \%$. The maximal values of protein and fat content were obtained for organic farming $(13.60 \%$ and $4.04 \%$, respectively), and the increase comparing with the conventional production was $4 \%$ and $3 \%$, respectively. The minimal fat value was obtained in conversion (3.72) and compared with organic farming the decrease was $37 \%$.

4. Rye: Rye samples exhibited similar value of ash in organic and conventional production ( $1.66 \%$ and $1.61 \%$, respectively). The values of protein and fat content, as well as of dry matter content were higher in organic than in conventional production and they were $10.41 \%, 1.70 \%$ and $88.45 \%$, respectively. The increase in protein and fat content in organic versus conventional production was $37 \%$ and $29 \%$, respectively, while the increase of ash and dry matter content was $3 \%$. In conversion maximal dry matter value was obtained and comparing with conventional farming, the increase was $1 \%$.

5. Millet: The values for the all quality parameters investigated were higher for organic production and their increase versus the values obtained for conventional production was the following: $71 \%$ for ash content, $3 \%$ for protein content, $7 \%$ for fat content and $1 \%$ for dry matter content.

Our earlier studies [17] on the influence of the variety, growing climate conditions and the production type on the oat fiber content, have shown that the fiber content was decreased for 5.8\% comparing to the conventional type of production. For protein content, it has been reported that organically-grown cereals, especially wheat, can have comparable protein levels with conventional ones, but generally have somewhat lower levels of protein than the conventional ones. The cultivars selected by organic farmers are mostly high-protein ones (e.g. for bread-making). A 25-30\% increase in lysine has been reported in organic wheat [18]. 


\section{CONCLUSION}

The results obtained from the research conducted revealed that there was a significant increase in the contents of ash, dry matter, protein and fat in organic produced cereals comparing with those produced either by conventional farming or in conversion. Most of analyzed quality parameters have shown maximal values almost in the all cereals analyzed, some were in conversion for wheat, barley and oat, while the all were higher for rye and millet.

Doubtless, besides the farming type, the influence on cereal quality has also the cereal kind, genotype, as well the production region, as we have determined before.

These results obtained in our investigations have confirmed that besides safety which is guaranteed in organic cereals and cereal food, a potential for improving the quality parameters of organic cereal grain can be expected. This is very important for the application of organic cereals in the animal and human nutrition.

Acknowledgement: This research has been undertaken in the frame of a scientific project supported by the Ss.Cyril and Methodius University in Skopje. The research team is grateful for the grant.

\section{REFERENCES}

[1] Menkovska Mirjana: The functional food based on cereals - its contribution for the health and wellbeing of the man, Book of Abstracts, The Ist Congress of Preventive Medicine of Macedonia, Ohrid, October 6-10, 1998.

[2] Menkovska, M.: Cereals in nutrition. Consumer Bulletin of Macedonia, 4, p. 7 (1999).

[3] Bauer, N., Gjorgovska, N., Menkovska, M., Filev, K.: Chemical composition of cereals in different processing phases. Bulletin of Macedonian Pharmaceutical Association, 41, 1-2, 340-341, Skopje (1995).

[4] Ivanoski, M., Menkovska, M.: Influence of climate factors during the formation of some wheat quality properties, Żyto Chleb, 17 (3), 71-74 (1990).

[5] Menkovska M.: Nutritive value of cereals intended for nutrition of monogastric animals, Final report on the three-year scientific project (1997-1999), "Ss.Cyril and Methodius University", Skopje, Institute of Animal Science, Skopje (1999) (In Macedonian).

[6] Menkovska Mirjana, Cilev, G.: Nutritional value of some kernel feedstuffs produced in Republic of Macedonia. Faculty with Farmers 2000", Proceedings of the, XXV Meeting", Faculty of Agriculture, University "Sts. Cyril and Methodius", Skopje, Macedonia, p. 175 (2000) (In Macedonian).

[7] Menkovska, M., Cilev, G.: Nutritive potential of some domestic cereals for nutrition of monogastric animals. Symposium of Livestock Production with International Participation, Sts Cyril and Methodius University, Skopje, Institute of Animal Science and Faculty of Agriculture, Proceedings, p. 223 (2002) (In Macedonian).

[8] M. Menkovska: Comparative analysis of nutrients contained in wheat and corn grown in different agro-ecological regions, EU-ICC Cereal Conference 2002, ECC 2002, Implementation of the European research Area, Vienna, Austria, March, 6-8, Book of Abstracts, 2002.

[9] Mirjana Menkovska: Comparative analysis on composition of macronutritive and antinutritive components of wheat and barley varieties, Program. XVII Congress of Chemists and Technologists of Macedonia (SHTM), Skopje, April 18-20, 2002, pp. 254-255.

[10] M. Menkovska, D. Zorić and S. Prodanović: Starch and crude fiber content of some bread wheat varieties, Proceedings of the ICC Jubilee Conference 1995. The role of cereals in future nutrition, Vienna, Austria (1995).

[11] M. Menkovska: Antinutritive components in cereals including animal feed, Conference handbook, $11^{\text {th }}$ Cereal and Bread Congress and $50^{\text {th }}$ Australian Cereal Chemistry Conference: Cereals, Health and Life, 8-15 September 2000, ANA Gold Coast Hotel, Surfers Paradise, Queensland, Australia (2000).

[12] Mirjana Menkovska, Goce Cilev: Improvement of nutritive value of some domestic cereals applied in animal nutrition. Final report on the three-year scientific project, "Ss. Cyril and Methodius" University, Skopje, Institute of Animal Science, Skopje (2002) (In Macedonian).

[13] http://ec.europa.eu/agriculture/organic/eu-policy/ index en.htm

[14] Council Regulation (EC) No 834/2007 of 28 June 2007, on organic production and labelling of organic products and repealing regulation (EEC), No 2092/91.

[15] European Parliament legislative resolution of 4 July 2012 on the proposal for a regulation of the European Parliament and of the Council amending Council Regulation (EC) No 834/2007 on organic production and labelling of organic products (COM(2010)0759 - C7-0001/2011 2010/0364(COD)).

[16] Macedonian low of agricultural production, food products and food, Official paper 146/2009, with changes and supplements of 14. 4. 2011.

[17] D. Spasova and M. Menkovska (2009): Comparative analysis of oat quality grown in organic and conventional conditions, Biotechnology in Animal Husbandry, Book 2, 25 (5-6), 1163-1170, and the $9^{\text {th }}$ International Symposium:"Modern Trends in Livestock Production", Belgrade, Serbia, October, 7-9 2009, Institute for Animal Husbandry, Belgrade-Zemun.

[18] Denis Lairon: Nutritional quality and safety of organic food. A review, Agron. Sustain. Dev. 30, pp, 33-41 (2011), INRA, EDP Sciences, 2010, DOI:10.1051/ agro/2009019 